\title{
Innovative teaching techniques for entrepreneurship education in the era of digitalisation
}

\author{
INESE MAVLUTOVA \\ Department of Economics and Finance \\ BA School of Business and Finance \\ Kr. Valdemara 161, LV-1013, Riga \\ LATVIA
}

\author{
KRISTAPS LESINSKIS \\ Department of Management \\ BA School of Business and Finance \\ Kr. Valdemara 161, LV-1013, Riga \\ LATVIA
}

\author{
MINDAUGAS LIOGYS \\ Software Development Department \\ Vilnius University of Applied Sciences \\ Saltoniskiu 58, LT-08105, Vilnius \\ LITHUANIA
}

\begin{abstract}
Nowadays, in the digital age, automated software with machine learning and artificial intelligence is widely used in both business and everyday life, therefore it has to be used in education and achieving of its sustainability. The young generation makes extensive use of a wide range of software, so teaching with an automated tool would be very attractive for students, but there is a need to increase teachers' digital skills and competencies. When studying entrepreneurship, students prefer innovative, practical teaching methods, involving automatic tools for validation of business idea feasibility.

The aim of the study is to identify multidisciplinary and innovative educational approaches and techniques in entrepreneurship, containing training that uses automated software to test and improve the viability of students' business ideas.

The authors followed the objectives of the Europe 2020 Strategy and the Entrepreneurship 2020 Action Plan. Digitalization creates and will create more and more possibilities in future to use automatic digital tools in education and solutions in form of artificial intelligence that might be scalable and widely applied for the distance learning as evidenced by the crisis caused by COVID-19.

The research is based on existing researches and comparative analysis of teaching entrepreneurship, statistical data analysis and survey conducted by authors. Discussion on and identification of innovative learning and teaching techniques in entrepreneurship education is also included.
\end{abstract}

Keywords: - entrepreneurship education, students' business idea viability, digitalisation, automatic software, teachers' digital competencies

Received: March 3, 2020. Revised: August 15, 2020. Re-revised: September 16, 2020. Accepted: October 21, 2020. Published: October 29, 2020.

\section{Introduction}

Digitalization creates and will create more and more possibilities to use automatic digital tools in education and solutions in a form of artificial intelligence that might be scalable and widely applied.

The necessity to increase students' business idea viability was identified given the evidence of the problems and challenges faced by teachers who teach entrepreneurship. There is a possibility to increase entrepreneurial aspirations through a development of new, attractive and innovative teaching and learning techniques in entrepreneurship.

This article is devoted to current issues of modern entrepreneurship education. With the emergence of artificial intelligence, professors, teachers and coaches are seeking for new approaches and techniques to teach entrepreneurship and revising the old ones.

Even though European Commission acknowledges that existing entrepreneurship education in the EU generally functions very good and generates pleasing results increasing the probability of starting business and lower possibility of becoming jobless for those who have participated in entrepreneurship education programs, there is a permanently ongoing discussion on necessity to use more and more innovative teaching methods, widely based on a complex mix of different learning and teaching approaches. 
The aim of the study is to identify multidisciplinary and innovative educational methods and techniques in entrepreneurship, including training using digitally automated software to test and improve the viability of students' business ideas.

The research is based on a critical literature analysis, discussion of existing research papers, quantitative survey, reports on entrepreneurial activity and youth entrepreneurship. The research contains also discussion and detection of innovative learning and teaching approaches, in particular, digital automatic software for education.

\section{Entrepreneurship education: innovative approaches and techniques}

Scientists have long studied business phenomena. Schumpeter suggested that entrepreneurs, not just companies, are responsible for the creation of new things in the search of profit [1]. Knight focused on entrepreneurs as the bearers of uncertainty and believed they were responsible for risk premiums in financial markets [2]. Kirzner thought of entrepreneurship as a process that leads to discovery [3].

An entrepreneur is an individual who starts and runs a business with limited resources and planning, and is responsible for all the risks and rewards of its business venture. The business idea usually encompasses a new product or service rather than exploiting an existing business models.

Entrepreneurship is one of the principal actors in every economy [4]. Ahmad and Seymour consider such widespread factors that encourage humans for entrepreneurship as the capacity for finding and exploiting a business opportunity and determination to follow the entrepreneur's behaviour [5]. Feldman and Bolino, as well as Katz, describe how the will to become an entrepreneur rest on the person's will as people apprise the possible outcomes, impact on economy and community [6], [7].

Drucker writes that fortunate entrepreneurs do not stand by waiting for creative ideas to come. Wouldbe innovators and entrepreneurs should go out of the company, listen and look, communicate and ask in a process of discovering [8].

Reacting to the significance of entrepreneurship as an important facilitator for growth of economy, entrepreneurship education programs have expanded globally with an objective to create the next generation of skilled entrepreneurs. Family links and academic education level also play important role in the entrepreneurs' lives and achievements [9], [10]. Some scientists emphasize the importance of entrepreneurship education and the role of the teacher in students' entrepreneurial intentions. Lefebvre, Baross have carried out different research related to business survival and expansion issues [11], [12].

When one looks at entrepreneurship as to the capability to create and implement innovative ideas in an entrepreneurial context, by logic extension, it may as well think of it as a part of the application scope for creative thinking [13]. Creativity therefore can be seen as a significant predecessor of entrepreneurial intensions and therefore individuals with a developed creative skills are more likely to engage in entrepreneurship [14].

Creativity is intrinsic to humans and should be, as Robinson describes, dealt with similarly and with the same importance as literacy [15]. It possesses value on its own, as De la Torre wrote, but merely when it generates value and comes to be an innovation. So fostering creativity is the first step to be innovative [16], [17]. If there is an inclination towards innovation, there will be a possibility for persons to become entrepreneurs. Barroso states that the creator has an idea, the inventor makes it work, the innovator provides value to that idea and the entrepreneur assumes the risk and brings it to the market and transforms it into a product [12].

Any business starts with an idea. Widespread and popular way to find a business idea is to consider familiar industry, while interests, hobby or developed skills and different other sources for initiatives can be welcomed as well. Evaluating the idea by attracting external expertise may be a good solution and can substantially assist to improvement of the idea. At the same time, the idea may be also rejected.

To implement any ideas, business plans are prepared where entrepreneurs create vision and set of activities for their business idea. It should be real, solid, contemplative, analyse current state and existing opportunities. It should discuss the strengths and weaknesses of the business. Every business plan is built on financial assumptions that analyses the potential viability and possible return on the investment for the potential investor, as well as gives insight into different financial indicators.

The education programs in entrepreneurship are typically considered to be an efficient way of promoting student's entrepreneurship. Still, these programs often emphasize just the acquiring of knowledge and expanding skills to set up a comprehensive business plan but in many cases do not initiate and develop the creative thinking [18].

Audretsch describes the important role of innovative teaching methods in developing an entrepreneurial mindset, behaviour and mentality in society [19]. Institutions of higher education with multidiscipli- 
nary profile and learning platforms have more important role on the way to the creation of new businesses and the commercialisation of scientific knowledge [20].

The invention of study programs fostering entrepreneurship, the participation of students and tutors in such activities as business plan competitions, entrepreneurship clubs, the field practice in real startups and other commercial organizations is crucial to develop entrepreneurship education programs more interactive and practical. Personal motivation of students, their understanding of the image of entrepreneurship, self-efficacy, enthusiasm, proactive approach, the desire to take risks are very important in teaching entrepreneurship.

Inspiration for creativity leads to the next dimension in process of entrepreneurship, that is, implementation phase of business idea. Young persons with creative minds can easier involve and participate in entrepreneurial activities, as they more clearly perceive the viability of a business idea and project. One of the efficient ways to encourage the creativity and entrepreneurial spirit is providing students with a real business environment and problem-solving situations, for example, business incubators.

Entrepreneurial studies also depend on demographic and other factors such as students' professional experience, gender, working experience of family members and other factors of impacting environment (communication and networks between the students and their participation in different communities of university life and meetings).

Neck and Greene identified the teaching methods and techniques for promotion of entrepreneurship at the university [21]. They established that to stimulate achievement of better outcomes, successful entrepreneurship study programs should contain a set of practice-based pedagogical approaches, business games, and simulations, design thinking and reflective practices should be used.

Institutional and international collaboration is an important facilitator in linking teachers with different experiences and competences and expands the vision towards the issue [22]. Actions of institutions of higher education (their internal policy and values) such as stimulus for innovations (their initiatives and internal objectives), the commercial orientation of the institution towards research and collaboration, and the preservation of intellectual property facilitate creation of new companies by students, and also assist to their successful development [23].

\section{The assessment of students' entrepreneur- ial intentions and assistance needed based on statistical data and survey}

To discuss the topic, authors performed the analysis of statistics on entrepreneurial intensions and actions as well as conducted survey among students in European countries. In 2018 and the beginning of 2019, the authors developed survey named KABADA to analyse entrepreneurial intensions, motivation, mindset, obstacles and desirable training among students of higher education in the European Union with an aim to analyse possibilities to launch new teaching approaches and techniques in entrepreneurship education. Even though the survey was spread in $16 \mathrm{Eu}-$ ropean countries, its main focused was put on five EU countries - Latvia and Lithuania from Eastern Europe, Belgium from Western Europe, Italy and Portugal from Southern Europe.

First, the authors analysed Global Entrepreneurship Monitor online statistics for selected countries and found that entrepreneurial intentions have declined recently in all of these countries [24].

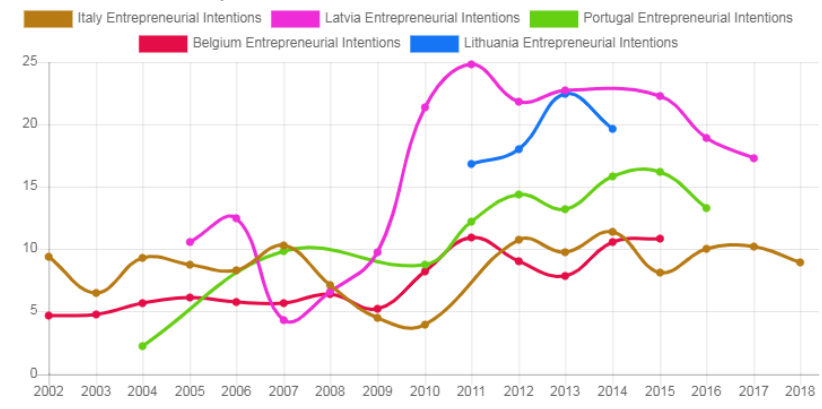

Fig. 1. The dynamics of entrepreneurial intentions in different EU countries (\% of adult population) [25]

As shown in Figure 1, entrepreneurial intentions are gradually declining in recent years as labour market opportunities have grown and labour markets have stabilized. Figure 1 shows that entrepreneurial intentions are closely linked to a new generation, namely the students' intentions, which in turn depend on the business education, and thus, it can be concluded that the traditional entrepreneurship teaching methods do not lead to growing students' desire to become an entrepreneur.

For investigation of regional differences in students' entrepreneurial intensions, the authors made a distinction between the old EU members (EU15 or those countries that were EU members already before 2004) and the new EU members (EU28-EU15 or those countries, which joined the EU in 2004 or later).

The following hypotheses were tested:

$\mathrm{H}_{0}$ - significant difference in answers' distribution by country groups doesn't exist 
$\mathrm{H}_{1}$ - significant difference in answers' distribution by country groups exists

To test the hypothesis, a chi-squared test was performed. All tests and subsequent computations were executed with JASP software (Version 0.9.2) and the p-value provided was verified:

If $\mathrm{p}$-value $>0.05, \mathrm{H}_{0}$ is true,

If $\mathrm{p}$-value $<0.05, \mathrm{H}_{1}$ is true.

The majority of respondents were bachelor's students $(86.5 \%)$, the rest were studying for a master's degree. Most of the respondents (70.3\%) studied in economics, finance or business management programs, the rest were from engineering, natural sciences, mathematics, information technology and education programs.

The survey's questionnaire can be divided in two main parts:

1) Analysis of students' professional career plans, including their entrepreneurial intentions;

2) Analysis of students' perception on necessary skills and training to become a successful entrepreneur.

Table 1 KABADA survey respondents' distribution by gender [26]

\begin{tabular}{|c|c|c|}
\hline \multicolumn{3}{|c|}{ Distribution of students by gender } \\
\hline Gender & Frequency & \% \\
\hline Male & 416 & 43.9 \\
\hline Female & 531 & 56.1 \\
\hline
\end{tabular}

Table 2 KABADA survey respondents' distribution by countries [26]

\begin{tabular}{|c|c|c|}
\hline \multicolumn{3}{|c|}{ Regional distribution of students } \\
\hline Countries & Frequency & \% \\
\hline The old EU members & 245 & 25.9 \\
\hline The new EU members & 659 & 69.6 \\
\hline Other & 43 & 4.5 \\
\hline
\end{tabular}

As Table 1 and Table 2 reflects, there is an insignificant disproportion in gender distribution of respondents (students). Most of the respondents (69.6\%) represented the new EU countries- Latvia and Lithuania. Majority of the respondents representing the old EU members group came from Italy, Portugal and Belgium.

Table 3 KABADA survey respondents professional life intentions [26]

\begin{tabular}{|l|c|c|}
\hline $\begin{array}{l}\text { Professional life intentions of stu- } \\
\text { dents }\end{array}$ & $\begin{array}{c}\text { Num- } \\
\text { ber }\end{array}$ & $\begin{array}{c}\text { Per- } \\
\text { cent }\end{array}$ \\
\hline have not decided yet & 225 & 23.8 \\
\hline $\begin{array}{l}\text { developing and managing own } \\
\text { business }\end{array}$ & 271 & 28.6 \\
\hline
\end{tabular}

\begin{tabular}{|l|c|c|}
\hline $\begin{array}{l}\text { Professional life intentions of stu- } \\
\text { dents }\end{array}$ & $\begin{array}{c}\text { Num- } \\
\text { ber }\end{array}$ & $\begin{array}{c}\text { Per- } \\
\text { cent }\end{array}$ \\
\hline $\begin{array}{l}\text { working for private or public or- } \\
\text { ganization as a specialist or man- } \\
\text { ager }\end{array}$ & 451 & 47.6 \\
\hline Total number of respondents & 947 & 100 \\
\hline
\end{tabular}

Table 3 shows that, although the most popular answer was related to the desire to be a salaried employee, almost $30 \%$ of students noted that they are intended to develop and manage their own business. This is a very high proportion, especially taking into account that almost one fourth $(23,8 \%)$ of the respondents have not decided yet about their career plans.

It should be noted that students of finance and management programs are high salary earners when they enter the labour market in their professions. It often discourages these professionals from turning to their possible risky entrepreneurial projects.

Further, the real number of students turning to entrepreneurship, will depend on opportunities, necessity, state support intensity and entrepreneurship education.

In survey, respondents were asked about what kind of knowledge and training they would prefer when working on their business ideas (several answers possible). The most popular answers were "finding financial sources" (65.4\%), "checking potential of my business ideas" (59.6\%) and "mentoring and consulting" $(52.9 \%)$. In the case of preferred assistance, $\mathrm{H}_{0}$ was true for all types of possible assistance with an exception of answer "checking potential of my business ideas" ( $\mathrm{p}$-value 0.016 ), where $\mathrm{H}_{1}$ turned out to be true.

Respondents were also asked about the skills that they lack or the knowledge they need to learn in order to be able to start an entrepreneurial activity (several answers possible). The most popular answers were "communication, leadership and general management skills" (54.5\%), "development of business ideas" (53.5\%), "financial management" (51.5\%) and "specific professional knowledge, skills and competencies related to industry" (49.4\%). Table 4 shows the results of testing $\mathrm{H}_{0}$ and $\mathrm{H}_{1}$ hypothesis: 
Table 4. Hypothesis test for country group differences in respondents' self-assessment regarding knowledge, skills and competencies they should have to start their own business [26]

\begin{tabular}{|l|c|c|}
\hline \multicolumn{1}{|c|}{ Answer } & p-value & $\begin{array}{c}\text { Hypothesis } \\
\text { true }\end{array}$ \\
\hline $\begin{array}{l}\text { Development of busi- } \\
\text { ness ideas }\end{array}$ & 0.016 & $\mathrm{H}_{1}$ \\
\hline $\begin{array}{l}\text { Assessment of busi- } \\
\text { ness potential of busi- } \\
\text { ness ideas }\end{array}$ & 0.153 & $\mathrm{H}_{0}$ \\
\hline $\begin{array}{l}\text { Communication, lead- } \\
\text { ership and general } \\
\text { management skills }\end{array}$ & 0.165 & $\mathrm{H}_{0}$ \\
\hline $\begin{array}{l}\text { Sales and marketing } \\
\text { skills }\end{array}$ & 0.479 & $\mathrm{H}_{0}$ \\
\hline $\begin{array}{l}\text { Financial management } \\
\text { skills }\end{array}$ & $<.001$ & $\mathrm{H}_{1}$ \\
\hline $\begin{array}{l}\text { Specific professional } \\
\text { knowledge, skills and } \\
\text { competencies related } \\
\text { to industry specifics }\end{array}$ & 0.045 & $\mathrm{H}_{1}$ \\
\hline
\end{tabular}

The results of the KABADA survey show that, despite the insignificant differences in understanding of required entrepreneurial skills and competencies between students from the old EU group and the new EU group, all students from selected European countries and different research programs are looking for an innovative approach to entrepreneurship teaching and learning, especially, through the use of digital techniques. This suggests that innovative software to test and increase the viability of students' business ideas, based on multidisciplinary experience, would unlock the EU's business potential, which is currently hampered by a lack of certain knowledge and skills.

Students learn better if they are provided with appropriate training and have the right knowledge, skills and competencies over time [27]. The following entrepreneurship teaching pathways are important: the critical thinking concepts of Caroll, Fobler and LeBlanc and UMICH, as well as the creativity components of Robbins \& Judge: competency, creative thinking abilities and intrinsic motivation [28], [29], [30], [31].

Teaching of real-world business cases is another approach to help students to develop both creative and feasible ideas. Case study method in business studies is efficient as the cases are developed through collaboration of real companies and institutions of higher education and thus place students in problem situations that companies have experienced and thus inspire and prepare them for sound decisions and solutions. They promote students to focus on real projects, interact with entrepreneurs and work on real business issues. By doing so, students are enabled to develop their creativity and ingenuity, in turn leading to an increased predisposition towards entrepreneurship [32]. Business cases related to startup success or fail stories are very beneficial in inspiring students to analyse and develop their own creative business ideas. Lefebvre conducted several studies dealing with business survival or development issues and came to conclusion that is important for students to keep in touch with entrepreneurs long after the case studies to prolong the mentoring and consulting [11].

Another innovative technique to teaching entrepreneurship is automatic digital software for assessment of business ideas.

\section{Creation and usage of automated software in teaching entrepreneurship}

Authors propose a software - AI based digital tool that could be able to assess the business idea of potential entrepreneurs. Unlike other business simulation applications or games, authors' proposed software will evaluate business plans based on past data, economic environment, business and industrial statistics as well as qualitative data provided by business experts. The software will give recommendations for business plan improvements, suggestions on financing sources for starting a business, possible partners. In order to make the tool function properly, authors are going to integrate machine learning to the software. Machine learning will be used in two ways:

- Reading (uploading) historical real-life data (business plans) to the software;

- Making conclusions about entrepreneur's business idea and giving recommendations.

In general, software will have the following features that create novelty in business education:

- Assessment of commercial viability and competitiveness of students' business idea.

- Assessment of innovativeness and creativity of students' business idea.

- Quantitative examination of necessary parts of business plan and its specific features.

- Qualitative analysis of the business plan (e.g. SWOT, PESTEL and other relevant tools).

- Analysis of the relevant personal characteristics and preconditions of potential entrepreneur (experience, mindset, skills, surrounding external preconditions etc.).

- Cognitive risks analysis of business plan (e.g. commercial, financial risks analysis) and simulation of potential risks.

- Recommendations for appropriate financial sources of financing the business plan, ability to attract financing from financial and government institutions (domestic, EU). 
- Recommendations on the legal form and country of incorporation of the company.

- Suggestions about potential partners (e.g. country, industry, social partners, suppliers, distributors, consultancy etc.) [33].

In general, software functionality can be seen in the conceptual framework reflected in Fig. 2.

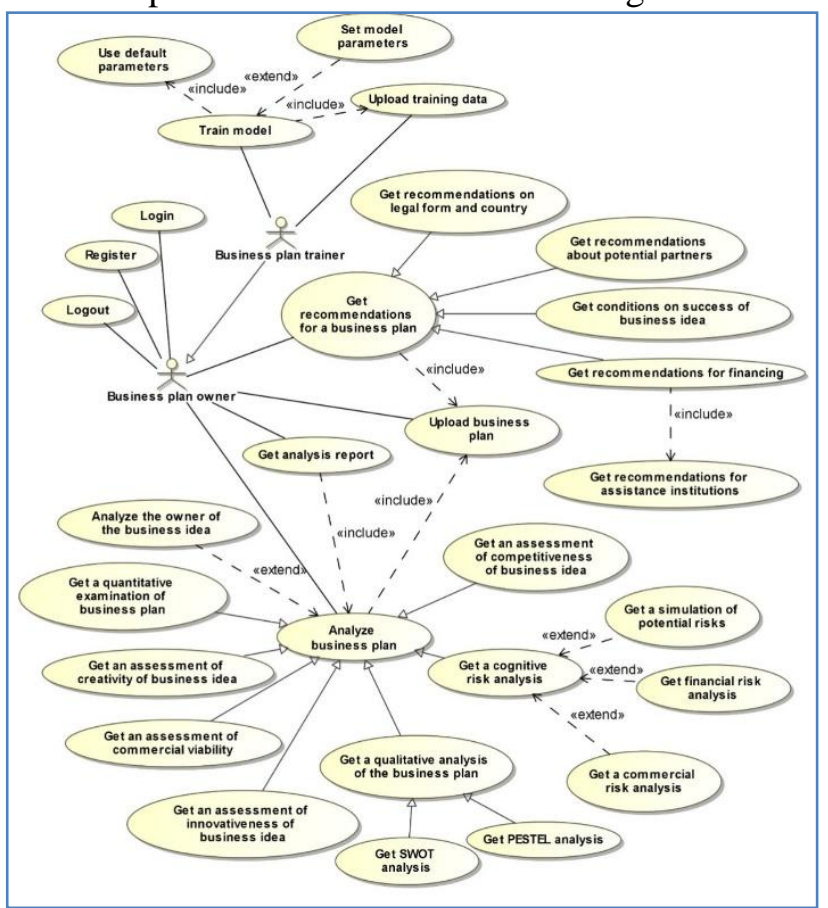

Fig. 2 Conceptual framework of digital automatic software usage

The software will have two groups of users: a business plan trainer and a business plan owner, a student or young entrepreneur who wants to test his or her business idea's viability. A business plan trainer will be responsible for artificial intelligence development, business plan owner for input his or her business plan.

Fig. 3 shows that the usage of digital automatic system tool in training consists of the following steps:

- Uploading initial data (historical data), the business plans known as successful or not successful.

- Pre-processing data by reducing its dimension, using dimension reduction algorithms such as Principal Component Analysis (PCA), Linear Discriminant Analysis (LDA) etc. [34], [35], [36].

- Based on a subset of all initial data, the system is trained using neural networks, linear classifiers [37], [38], [39], [40]. A model that identifies the probability of success of the business plan is then created.

- Using the remaining subset, the model will be tested - mutually validated [41]. If the test fails, the trainer repeats the training process (step 2) using different parameters or different methods. If the test is successful, the system training can be considered complete.

Some relevant studies can be found in [42] and [43].

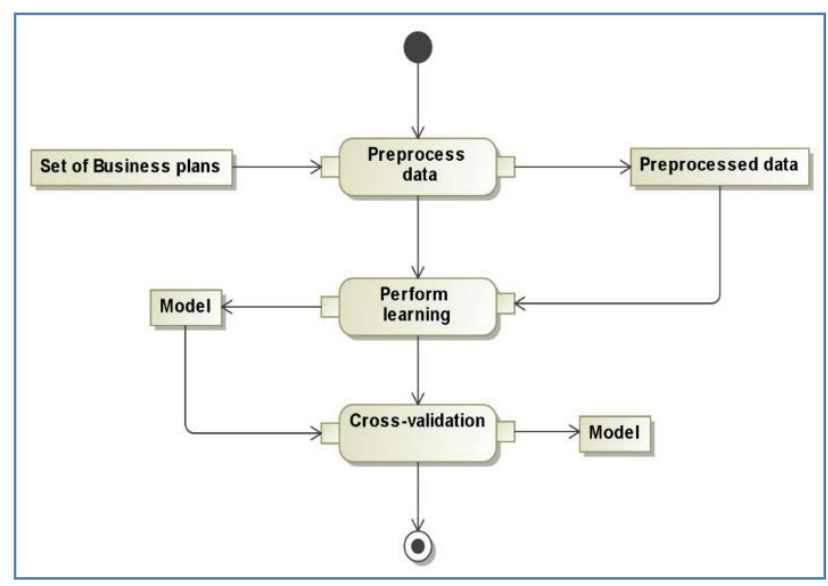

Fig. 3 The basic model of the functioning of the digital automatic system

The authors conclude that the institutions of higher education and their professors have to adapt new multidisciplinary approaches to their studies in order to remain competitive and meet the needs of the economy in the European Union, taking advantage of the new opportunities offered by the development of artificial intelligence and machine learning. The development of the described software would bring teaching entrepreneurship to the new quality level and make it more efficient both from perspective of teacher and learner. There will be also aspect of multidisciplinary approach included as the tool can be easily used for students from different fields and backgrounds. The main goal of such tool is to increase companies' survival rate, at the same time to reduce companies closing rate. Authors proposed tool will let the entrepreneurs to test their ideas before actually starting business.

University policy towards innovations (initiatives and internal goals), the commercial orientation of the university towards research and cooperation and the preservation of intellectual property, the frequency of communication with the teaching teams and an extended network of communication as well as the external relations, contribute not only to teaching entrepreneurship, but also to the creation of new businesses and their successful development [44], [45]. International and inter-institutional cooperation not only helps to link teachers with different competencies, but also expands the spectrum of views concerning issues under discussion. 


\section{Conclusions}

The authors conclude that there are weak entrepreneurial intentions among young people in Europe by global standards, but at the same time, significant part of students in European Union have high entrepreneurial intensions and even growingly perceive opportunities in business.

Innovative entrepreneurship education plays a crucial role in promoting entrepreneurship. The authors identified students' needs for consulting, mentoring, skills to attract financial resources to start a business and test the viability of their business ideas using automated digital software as preferred entrepreneurship learning methods and techniques.

Entrepreneurship education requires new innovative approaches and techniques, for example, involving students in activities such as business plan competitions, business clubs and practical training undertaken in startups, as well as a distance learning through international cooperation.

To stimulate entrepreneurial intentions among students, teachers and professors should use developed practical tools like automatic digital software for assessment of business ideas of young entrepreneurs, checking of financial plans through automatic digital systems, to adapt them and to include such practices in course syllabus, thus offering better education practices. Such an approach requires a significant improvement in teachers' digital competencies.

It should be taken into account that the survey conducted by the authors contain certain limitations. It was mostly focused on business and economics students, while nowadays a lot of entrepreneurs come from technology, engineering, mathematics, healthcare and other study directions.

The authors continue their research and apply the obtained data in construction of practical digital tool that will check the business ideas and plans, and will automatically generate suggestions to users. Therefore, this study is essential in providing practical benefits to the community of business educators and consultants.

\section{Acknowledgements}

The paper is based on the research in BA School of Business and Finance Internal project Application of modern teaching methods in business studies in higher education.

\section{References:}

[1] J. Schumpeter, "Capitalism in the postwar world, in Harris S. (eds.)," in Postwar Economic Problems, 1943, pp. 98-125.

[2] F. Knight, Risk, Uncertainty and Profit, Houghton Mifflin, 1921.

[3] I. Kirzner, Competition and Entrepreneurship, University of Chicago Press, 1973.

[4] D. Salinas and F. Barroso, "Efficacy of a program for increasing motivation for entrepreneurshipand employees productivity one year after it was implemented," in Proceedings of the IAnahuacMayab International Research Congress in Administrative Science, 2016.

[5] N. Ahmad and R. Seymour, "Defining entrepreneurial activity: definitions supporting frameworks for data collection," [Online]. Available: http://www.oecd.org/officialdocuments/publi cdisplaydocumentpdf $/$ ?doclanguage $=e n \& \cot$ $\mathrm{e}=\mathrm{std} /$ doc. [Accessed 0904 2019].

[6] C. Feldman and C. Bolino, "Career Patterns of the Self-employed: Career Motivations and Career Outcomes," in Journal of Small Business Management, Vols. 19, No. 38, 2000, pp. 53-67.

[7] J. Katz, "Modeling Entrepreneurial Career Progressions: concepts and considerations," in Entrepreneurship: Theory and Practice, Vols. 2, No. 19, 1994, pp. 23-24.

[8] P. Drucker, "The Discipline of Innovation," in Harvard Business Review, 2002.

[9] F. Barroso, "Factores y razones para desarrollar la creatividaden las empresas[Factors and reasons for developing creativity in enterprises. A study in the Southeas tof Mexico]," in Revista de CienciasSociales, Vols. 18, No. 3, 2012, pp. 509-516.

[10] D. Salinas, Entrepreneurship competencies ,motivation for entrepreneurship and productivity. A study in the Southeast of Mexico, Anahuac Mayab University, 2014.

[11] Q. Lefebvre, "Inspiring Entrepreneurship through Creative Thinking," in The Transforming Power of the Entrepreneurship and Innovation Ecosystem: Lessons Learned, 2018, pp. 131-137. 
[12] F. Barroso, "Motivation for increasing creativity, innovation and entrepreneurship. An experience from the classroom to business firms," in Journal of Innovation Management, Vols. 5, No. 3, 2017, pp. 55-74.

[13] T. M. Amabile, "Entrepreneurial creativity through motivational synergy," in Journal of Creative Behavior, Vols. 31, No. 1, 1997, pp. 18-26.

[14] T. Ward, "Cognition, creativity, and entrepreneurship," in Journal of Business Journal of Business Venturing, Vols. 19, No. 2, 2004, pp. 173-188.

[15] K. Robinson, Director, Do schools kill creativity?. [Film]. 2006.

[16] S. De la Torre, Creatividad y formación: identificación, diseño y evaluación[Creativity and formation: identification, design and evaluation], Trillas, 1997.

[17] P. Gupta, The Innovation Solution. Making Innovation More Pervasive, Predictable and Profitable, Create Space Independent Publishing Platform, 2012.

[18] A. Sagie and D. Elizur, "Achievement motive and entrepreneurial orientation: A structural analysis".

[19] D. B. Audretsch, "From the entrepreneurial university to the university for the entrepreneurial society," in Journal of Technology Transfer, Vols. 39, No. 3, 2014, pp. 313-321.

[20] A. Bonaccorsi, M. Colombo, M. Guerini and C. Rossi-Lamastra, "University specialization and new firm creation across industries," in Small Business Economics, Vols. 41, No. 4, 2013, pp. 837-863.

[21] H. Neck and P. Greene, "Entrepreneurship Education: Known Worlds and New Frontiers," in Journal of Small Business Management, Vols. 49, No. 1, 2011, pp. 5570.

[22] Ž. Baubonienė, H. Ho, A. Puksas and E. Malinauskienè,, "Factors Influencing student entrepreneurship intentions: the case of Lithuania and South Korean Universities," in Entrepreneurship and Sustainability, Vols. 6, No. 2, 2018, pp. 854-871.

[23] B. Clarysse and N. Moray, "A process study of entrepreneurial team formation: the case of a research-based spin-off," in Journal of Business Venturing, Vols. 19, No. 1, 2004, pp. 55-79.
[24] "Entrepreneurial Behaviour And Attitudes," [Online]. https://www.gemconsortium.org/data. [Accessed 1202 2019].

[25] I. Mavlutova, M. Krastiņš, J. Hermanis and K. Lešinskis, "Student-centered methods in entrepreneurship education to increase entrepreneurial intentions of students," in LitteraScripta, Vols. 12, No. 2, 2019, pp. 4966.

[26] "KABADA Survey," [Online]. Available: https://kabada.eu/. [Accessed 1207 2019].

[27] H. Min, "Training students to become successful peer reviewers," in System, Vol. 33, pp. 293-308.

[28] R. Caroll, Becoming a Critical Thinker. A Guide for the New Millennium, Pearson Publishing, 2000.

[29] H. Fobler and S. LeBlanc, Strategies for Creative Problem Sol, Prentice Hall, 1995.

[30] UMICH, "Problem Solving. Critical and Creative thinking," [Online]. Available: http://www.umich.edu/ elements/5e/probsol $\mathrm{v} / \mathrm{strategy/crit-n-creat.html.} \mathrm{[Accessed} 1806$ 2019].

[31] S. Robbins and T. Judge, Comportamiento organizacional [Organizational behavior] 15th edn, Pearson Prentice Hall, 2013.

[32] N. Peterman and J. Kennedy, "Enterprise education: Influencing students' perceptions of entrepreneurship. Entrepreneurship," in Theory and Practice, Vol. 28, 2003, pp. 129144.

[33] I. Mavlutova, K. Lesinskis, M. Liogys and J. Hermanis, "The Role of Innovative Methods in Teaching Entrepreneurship in Higher Education: Multidisciplinary Approach,," in Reliability and Statistics in Transportation and Communication, 2020, pp. 684-693.

[34] Y. Mori, M. Kuroda and N. Makino, Nonlinear Principal Component Analysis and Its Applications. JSS Series in statistics, Springer, 2016.

[35] P. Srinivasu, P. Avadhani, S. Satapathy and T. Pradeep, "A Modified Kolmogorov-Smirnov Correlation Based Filter Algorithm for Feature Selection," in Proceedings of the International Conference on Information Systems Design and Intelligent Applications 2012, Springer, 2012, pp. 819-826. 
[36] J. Schmidhuber, "Deep Learning in Neural Networks: An Overview," in Neural Networks, Vol. 61, 2015, pp. 85-117.

[37] H. Bhavsar and A. Ganatra, "Variations of Support Vector Machine Classification Techniques: A survey," in International Journal of Advanced Computer Research, Vols. 2, No. 4, 6, 2012, pp. 223-227.

[38] A. Ciaccio and G. M. Giorgi, "Deep Learning for Supervised Classification," in Rivista Italiana di Economia Demografia e Statistica, Vols. 64, No. 2, 2015, pp. 1-10.

[39] Z. Qawaqneh, A. Abu Mallouh and B. Barkana, "DNN-based Models for Speaker Age and Gender Classification," in Proceedings of the 10th International Joint Conference on BiomedicalEngineering Systems and Technologies, 2017, pp. 106111.

[40] D. Fradkin and I. Muchnik, Support Vector Machines for Classification, DIMACS Series in Discrete Mathematics and Theoretical Computer Science, The State University of New Jersey, 2000.

[41] Q. Gronau and E. Wagenmakers, "Limitations of Bayesian Leave-One-Out Cross-Validation for Model Selection," in Computational Brain \& Behavior, Vols. 2, No. 1, 2018, pp. 1-11.

[42] L. Olcomendy, F. Santos-Cessac and P. Dondon, "Design of a low cost LIDAR scanning system for didactical applications," in International Journal of Circuits, Systems and Signal Processing, Vol. 13, 2019, pp. 336-372.

[43] Y. Tingting, "Research on the Risk Crisis Prediction of Enterprise Finance by Genetic Algorithm," in International Journal of Circuits, Systems and Signal Processing, Vol. 12, 2019, pp. 319-324.

[44] Z. Todorovic, R. McNaughton and P. Guild, "ENTRE-U: An entrepreneurial orientations cale for universities, Technovation," 2011. [Online].

Available: https://doi.org/10.1016/j.technovation.2010.1 0.009. [Accessed 1605 2019].

[45] A. Grandi and R. Grimaldi, "Exploring the Networking Characteristics of New Venture Founding Teams," in Small Business Economics, Vols. 21, No. 4, 2003, pp. 329341 .

\section{Creative Commons Attribution License 4.0 (Attribution 4.0 International, CC BY 4.0)}

This article is published under the terms of the Creative Commons Attribution License 4.0 https://creativecommons.org/licenses/by/4.0/deed.en_US 